\title{
Nonoperative Management in Blunt Liver Trauma: A Study done in a Tertiary Care Hospital of a Hilly State in India
}

\author{
${ }^{1}$ Vijay S Chandel, ${ }^{2}$ Lata R Chandel, ${ }^{3}$ Arun Chauhan, ${ }^{4}$ Parikshit Malhotra, ${ }^{5}$ Arun K Gupta
}

\begin{abstract}
Aim: To evaluate the efficacy of nonoperative treatment in blunt trauma liver.

Materials and methods: A 1-year prospective study was conducted in the Department of Surgery, Indira Gandhi Medical College (IGMC), Shimla, Himachal Pradesh, India, on 31 patients with blunt trauma with liver injuries proved on ultrasonography (USG) focused assessment with sonography for trauma (FAST) and contrast-enhanced computed tomography (CECT) abdomen. Once admitted, patients with grades I or II liver injury with no other comorbidities and other associated injuries were managed conservatively. Patients with grades III, IV, or $\mathrm{V}$ liver injury or lower grade liver injury with other associated injuries were observed and monitored strictly. Patients were considered a failure if the patient developed signs of peritonitis.
\end{abstract}

Results: Out of 83 patients with blunt abdominal trauma, 31 patients fulfilled the inclusion criteria for nonoperative management (NOM). The incidence of blunt liver trauma (BLT) was $37.34 \%$ Out of these, one patient required operative management (OM). Average age was 27 years. Out of 31 patients, $25(80.6 \%)$ patients were males and $6(19.4 \%)$ were females. Totally, $24(77.4 \%)$ patients acquired injury due to road side accidents. Totally, $25(80.6 \%)$ patients reported to the hospital within 6 hours of injury and $5(16.1 \%)$ within 7 to 12 hours. On grading of liver injuries depending on CECT findings, 6 (19.4\%) patients presented with grade I injury, $7(22.6 \%)$ patients with grade II injury, 11 (35.5\%) with grade III injury, and $6(19.4 \%)$ with grade IV injury. Grade V injury was noted in $1(3.2 \%)$ patient. Sixteen patients required blood transfusion. The NOM was successful in $96.8 \%$ of the patients. Liver-specific success rate of NOM was $100 \%$. Mean hospital stay was 10.8 days for NOM.

Conclusion: Patients of blunt liver injury who are hemodynamically stable should be considered for NOM.

Clinical significance: The NOM is a highly feasible and safe method for being cost-effective, requiring shorter hospital stay, and avoiding high morbidity.

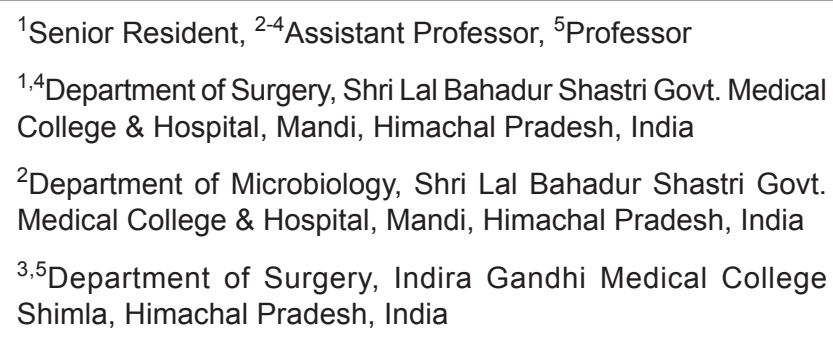

Corresponding Author: Lata R Chandel, Assistant Professor Department of Microbiology, Shri Lal Bahadur Shastri Govt. Medical College \& Hospital, Mandi, Himachal Pradesh, India Phone: +919418004508, e-mail: drlatachandel@gmail.com
Keywords: Blunt trauma, Nonoperative management, Prospective study, Road traffic accident.

How to cite this article: Chandel VS, Chandel LR, Chauhan A, Malhotra P, Gupta AK. Nonoperative Management in Blunt Liver Trauma: A Study done in a Tertiary Care Hospital of a Hilly State in India. Panam J Trauma Crit Care Emerg Surg 2018;7(1):33-37.

\section{Source of support: Nil}

Conflict of interest: None

\section{RESUMEN}

Objetivo: Evaluar la eficacia del tratamiento conservador en trauma hepático.

Material y métodos: En un estudio prospectivo de 1 año se llevó a cabo en el Departamento de Cirugía, Indira Gandhi Medical College (IGMC), Shimla, Himachal Pradesh, India, en 31 pacientes con trauma contuso con lesiones hepáticas resultó en la ultrasonografía (USG) centra la evaluación con ecografía para trauma (FAST) y la tomografía computarizada con contraste mejorado (CECT) del abdomen. Una vez admitidos, los pacientes con grados I o II de lesión hepática sin otras comorbilidades y otras lesiones asociadas fueron tratados de forma conservadora. Los pacientes con grado III, IV o V de lesión hepática o menor grado de lesión hepática con otras lesiones asociadas fueron observados y controlados de forma rigurosa. Los pacientes fueron considerados un fracaso si el paciente desarrolla signos de peritonitis.

Resultados: De los 83 pacientes con trauma abdominal cerrado, 31 pacientes cumplieron los criterios de inclusión para el tratamiento conservador (NOM). La incidencia de trauma hepático romo (BLT) fue de $37,34 \%$, una de las cuales requiere de paciente gestión operativa $(\mathrm{OM})$. El promedio de edad fue de 27 años. De los 31 pacientes, 25 (80.6\%) pacientes fueron varones y $6(19,4 \%)$ eran mujeres. Totalmente, $24(77,4 \%)$ pacientes adquirieron lesiones debidas a los accidentes de carretera. Totalmente, $25(80,6 \%)$ de los pacientes comunicaron al hospital dentro de las 6 horas de la lesión y 5 $(16,1 \%)$ en un plazo de 7 a 12 horas. En la clasificación de las lesiones hepáticas en función CECT conclusiones, 6 (19,4\%) pacientes presentaron lesiones de grado I, $7(22,6 \%)$ pacientes con lesiones de grado II, 11 (35,5\%) con lesiones de grado III y $6(19,4 \%)$ con lesiones de grado IV. Las lesiones grado $V$ se observó en 1 pacientes (3,2\%). Dieciséis pacientes requirieron transfusión de sangre. EI NOM fue exitosa en $96.8 \%$ de los pacientes. Específicas del hígado la tasa de éxito de NOM fue del $100 \%$. La estancia media hospitalaria fue de 10,8 días para NOM.

Conclusión: Los pacientes de lesión hepática contundentes que son hemodinámicamente estable debe ser considerado para el NOM. 
Significado clínico: La NOM es un método seguro y altamente factible para ser rentable, requiriendo una menor estancia hospitalaria, y evitar la alta morbilidad.

Keywords: Accidente de tráfico, Prospectivo, Tratamiento conservador, Trauma contuso.

\section{INTRODUCTION}

Since earliest times, trauma has been a constant companion of man. ${ }^{1}$ Liver is one of the most commonly injured solid intraabdominal organs in blunt abdominal injuries due to its fixed position. ${ }^{2}$ Liver injuries have been reported in 35 to $45 \%$ of patients with significant blunt abdominal trauma. ${ }^{3}$ Common causes of blunt abdominal trauma are RSAs in adults and accidental fall from height in children. On Hepatic Injury Scale established by the American Association for the Surgery of Trauma, hepatic injury is graded from I to VI. ${ }^{4}$ The management of BLT has changed dramatically in recent decades. High-quality CECT scan plays a pivotal role in enabling NOM of intra-abdominal solid organ injury. Current studies demonstrate that 70 to $90 \%$ of liver injury patients, who are hemodynamically stable, do not require surgical intervention..$^{5-8}$ Recent literature depicts up to $98 \%$ of success rate with NOM in selected cases. ${ }^{5,7}$, The mortality rate for liver injuries managed conservatively ranges from 0 to $0.4 \%$ in recent reports. ${ }^{6-9}$ Overall, in the current scenario, 82 to $100 \%$ of patients with blunt trauma to the liver are being managed nonoperatively. ${ }^{10}$ Further, NOM is cost-effective, requires shorter hospital stay, and avoids high morbidity.

The intention of the present study was to find the efficacy of nonoperative treatment in blunt trauma liver in the Department of General Surgery in IGMC, Shimla, Himachal Pradesh, India.

\section{MATERIALS AND METHODS}

A prospective study was conducted in the Department of Surgery, IGMC, Shimla, Himachal Pradesh, India, on 31 patients of blunt trauma with liver injuries over a 1-year period from May 1, 2014 to April 30, 2015. The liver injuries were proved on USG FAST and CECT abdomen. All patients and their attendants were fully explained about the nature and aim of the present study, and informed consent was taken from them.

Patients diagnosed with coagulation abnormalities, grade VI liver injuries (diagnosed on CT abdomen), injuries other than liver trauma requiring operative intervention, penetrating, stab, and gunshot injuries, or hemodynamically instable after resuscitation were excluded from the study.

After doing the patients quick assessment, resuscitation was done. Intravenous fluids were given and patients were catheterized. Blood grouping and cross-match along with other blood investigations were sent. Fluid resuscitation was planned as per central venous pressure reading after putting the central line in hemodynamically unstable patients where peripheral intravenous access was difficult. Patients were investigated as follows after patients were stabilized:

- Blood: Hemoglobin, total leukocyte count, bleeding time, clotting time, and liver and renal function tests.

- Serial hematocrit value

- Urine: microscopy

- Chest X-ray

- X-ray erect abdomen

- Ultrasound FAST

- Computed tomography (64-slice multidetector CT) scan of the abdomen if not done earlier, provided patient was hemodynamically stable

- Additional investigations as were deemed necessary according to the injury inflicted.

Once admitted, patients with grades I or II liver injury with no other comorbidities were kept in surgery wards under conservative treatment. Patients with grades III, IV, or V liver injury or lower grade liver injury with other associated injuries were kept under observation and strict monitoring in intensive care unit wards. Patients were subsequently evaluated in detail regarding history and physical examination. All details were duly noted on the pro forma prepared for the study.

Patients were classified according to early management in the first 6 hours after arrival. Patients undergoing laparotomy or other open liver procedures in the first 6 hours were considered to have received OM and were in OM group. The remaining patients who did not require any surgery were treated conservatively and were in the NOM group. Patients managed with nonoperative treatment were evaluated clinically as well as biochemically. The blood transfusion requirement was also duly noted. Hemodynamically stable patients underwent a repeat ultrasound after 5 to 7 days to assess intra-abdominal collections.

All patients with satisfactory improvement were discharged and followed up in surgery outpatient department clinically as well as with necessary investigations.

Patients were considered a failure for nonoperative treatment in the following cases:

- When there is serial fall in hematocrit, i.e., a drop in the hematocrit greater than $20 \%$ in the first hour or patients requiring higher amounts, i.e., more than 4 units of blood transfusion in first 6 hours following admission.

- If patient developed signs of peritonitis.

In these cases, NOM was abandoned, laparotomy was done, and surgical procedures were done depending 
Nonoperative Management in Blunt Liver Trauma

\begin{tabular}{ll}
\hline \multicolumn{2}{c}{ Table 1: Signs at presentation } \\
\hline Sign & Number (Percentage) \\
\hline Tenderness & $24(77.4)$ \\
External injury marks & $15(48.4)$ \\
Distension & $10(32.2)$ \\
Guarding & $01(3.2)$ \\
Rigidity & $01(3.2)$ \\
\hline
\end{tabular}

Table 3: Grades of liver injury with whole blood transfusion

\begin{tabular}{lllllll}
\hline GOI & $1 U$ & $2 U$ & $3 U$ & $4 U$ & $5 U$ & No of patients \\
\hline I & - & - & - & - & - & - \\
II & 1 & & & & 1 & 2 \\
III & - & 5 & 1 & 1 & - & 7 \\
IV & - & - & 1 & 5 & - & 6 \\
V & - & - & - & - & 1 & 1 \\
Total & 1 & 5 & 2 & 6 & 2 & 16 \\
\hline
\end{tabular}

on operative findings. The data of all the patients were thoroughly recorded and evaluated statistically.

\section{RESULTS}

Out of 83 patients with blunt abdominal trauma who reported in the Emergency Department of IGMC, Shimla, during the study period, 31 patients fulfilled the inclusion criteria and were selected for NOM. The incidence of BLT came out to be $37.34 \%$ among blunt abdominal trauma patients. Out of these, one patient developed peritonitis and became hemodynamically unstable, thus requiring OM. On laparotomy, there was perforation in the jejunum, but liver injury was healed. So, in this case, failure of NOM was due to a cause other than liver injury.

Maximum number of patients were in the age group of 21 to 30 years in this study. Average age for blunt liver injury patients was 27 years. Out of 31 patients, $25(80.6 \%)$ patients were males and $6(19.4 \%)$ patients were females, with male-to-female ratio of 4.2:1. Out of 31 patients, 24 (77.4\%) patients acquired injury due to RSAs. History of fall was found to be responsible for liver injury in 7 (22.6\%) patients. Totally, $25(80.6 \%)$ patients reported to the hospital within 6 hours of injury, $5(16.1 \%)$ patients within 7 to 12 hours of injury, and 1 (3.2\%) patient reported after more than 12 hours of injury. All the patients had GCS $15 / 15$. Urinary output of all the patients was within normal limits during resuscitation period. On initial examination, at presentation was as per the signs given in Table 1.

On USG FAST, free fluid was present in all of the 31 patients, but exact grade of injury (GOI) could not be identified for which CECT abdomen was done. Grading of liver injuries as per CECT findings is as indicated in Table 2.

Blood tests done were hemoglobin, hematocrit, liver function tests, such as serum glutamic oxaloacetic
Table 2: Grade of injury

\begin{tabular}{lll}
\hline GOI & Total number of patients & Percentage \\
\hline I & 6 & 19.4 \\
II & 7 & 22.6 \\
III & 11 & 35.5 \\
IV & 6 & 19.4 \\
V & 1 & 3.2 \\
Total & 31 & 100 \\
\hline
\end{tabular}

Table 4: Average duration of hospital stay as per GOI

\begin{tabular}{llll}
\hline GOI & Total days & Total pts. & Avg. days \\
\hline I & 66 & 6 & 11.0 \\
II & 82 & 7 & 11.71 \\
III & 118 & 11 & 10.73 \\
IV & 68 & 6 & 11.33 \\
V & 12 & 1 & 12.0 \\
\hline
\end{tabular}

transaminase, serum glutamic pyruvic transaminase, alkaline phosphatase, total bilirubin, direct bilirubin, total serum protein, serum albumin, renal function tests, i.e., urea and creatinine. Besides this, serum calcium and arterial blood gas analysis were done. These investigations were repeated after 12 hours, 24 hours, 2 days, and 7 days.

Blood transfusion was required in $16(51.6 \%)$ patients. Number of whole blood units transfused ranged from 1 to 5 units in these patients as per the hemodynamics. Blood transfusion requirement increased with the severity of liver injury or in patients with associated other injuries, as was found during the observation of patients (Table 3).

Hospital stay varied from 7 to 16 days for NOM in 30 $(96.8 \%)$ patients. In one patient, NOM was abandoned due to missed bowel injury, and he stayed in the hospital for 21 days. Average duration of hospital stay in NOM patients came out to be as shown in Table 4. Duration of average hospital stay in grades I, II, and III patients in our study was found to be similar to grades IV and V injuries as most of the patients belonged to farflung areas of hilly difficult terrain of this state without modern health and transportation facilities. Henceforth, to avoid any untoward complications, the patients were kept under observation for long.

Overall, 30 (96.8\%) patients responded to conservative, i.e., NOM of BLT. Failure of NOM was observed in $1(3.2 \%)$ patient.

\section{DISCUSSION}

Incidence of blunt abdominal trauma is on the rise because of use of motor vehicles, and increase in crime and violence. In our study, the mean age of patients of blunt liver injury was 27 years. Maximum number of patients were in the age group 21 to 30 years. Similar findings are found in other studies. ${ }^{11-14}$ The study had 
a male preponderance accounting to $80.6 \%$. Gad et al ${ }^{15}$ demonstrated significant difference between involvement of males as compared with females, in abdominal trauma ( 87.1 vs $12.9 \%)$. This is because males are more exposed to outdoor activities. Road side accident is the commonest cause of blunt abdominal trauma. In our study, RSAs were responsible for $77.4 \%$ cases. History of fall was responsible for liver injury in $22.6 \%$ patients. In a study by Magray et $\mathrm{al}^{16}$ the most common cause of abdominal injury was RSA (59\%) followed by fall from height (26\%). Similarly, Emery et a ${ }^{17}$ reported that 51\% had RSA and $18 \%$ had fall from height in their study. In our study, $80.6 \%$ patients reported within 6 hours of injury to the hospital, $16.1 \%$ patients reported within 7 to 12 hours of injury, and only $3.2 \%$ patient reported after more than 12 hours of injury. In the present study, the most common symptom was pain abdomen (100\%). In a study by Magray et $\mathrm{al}^{16}$ abdominal pain was the most common symptom observed in blunt abdominal trauma patients $(77 \%)$. Abdominal tenderness was the most common sign observed (72\%). Blood transfusion is an important element of NOM. In our study, blood transfusion was required in $16(51.6 \%)$ patients with average units of whole blood transfused being 3.19 units. Number of units transfused ranged from 1 to 5 units in these patients. In our study, it was seen that more than 4 units of blood transfusion requirement was associated with hemodynamic instability and indicated need for exploration in only one patient. Our observation is supported by literature, which says that failure rates are higher among patients receiving more than 4 units of blood transfusions. ${ }^{18-20}$ In our study, as per CECT, grading of liver injuries was done. Totally, $6(19.4 \%)$ patients had grade I injury, 7 (22.6\%) patients grade II injury, 11 (35.5\%) patients grade III injury, and $6(19.4 \%)$ patients had grade IV liver injury. Grade V liver injury was noted in only 1 (3.2\%) patient. Out of these, $96.8 \%$ patients responded to conservative, i.e., NOM of BLT. Liver specific success rate of NOM was $100 \%$ as NOM had to be abandoned in one case due to the cause-other than liver injury. Similar findings were reported in the study by Velmahos et $\mathrm{al}_{1}{ }^{14}$ which demonstrated the success rate of NOM of BLI as $85 \%$, but the liver-specific success rate was $100 \%$. In our study, mean hospital stay was 10.8 days for NOM patients. Only one patient who was managed surgically remained for 21 days in the hospital. Velmahos et $\mathrm{al}^{14}$ and Duane et $\mathrm{al}^{21}$ found the same results with $\mathrm{p}=0.02$. In our study, group $1(3.2 \%)$ patients had missed bowel injury, which was not detected on presentation CECT abdomen, and patient was selected for conservative management. Various studies have shown 1 to $3 \%$ incidence of missed bowel injury with conservative management. ${ }^{22-24} \mathrm{No}$ patient died in our study group. Our results are supported by the recent reports of literature, which show the mortality rate for liver injuries undergoing NOM to lie between 0 and $0.4 \% .6,9$

\section{CONCLUSION}

Patients of blunt liver injury who are hemodynamically stable can be managed nonoperatively irrespective of the grade of hepatic injury. The NOM of blunt liver injury is associated with a low overall morbidity and mortality.

\section{CLINICAL SIGNIFICANCE}

The NOM should be the choice of treatment in BLT as it is a highly feasible and safe method. It is cost-effective, requires shorter hospital stay, and avoids high morbidity.

\section{REFERENCES}

1. Cusheri A, Giles GR, Moosa AR, editors. Essential surgical practice: 3rd ed. Oxford: Butterworth International; 1998. p. 263-304.

2. Zangana AM. Penetrating liver War injury: a report on 676 cases, after Baghdad invasion and Iraqi Civilian War April 2003. J Adv Med Dent Sci 2007 Sep;1(1):10-14.

3. Feliciano DV, Rozycki GS. Hepatic trauma. Scand J Surg 2002;91(1):72-79.

4. Silvio-Estaba L, Madrazo-González Z, Ramos-Rubio E. Actualización del tratamiento de los traumatismos hepáticos. Cirugía Española 2008 May;83(5):227-234.

5. Pachter HL, Knudson MM, Esrig B, Ross S, Hoyt D, Cogbill T, Sherman H, Scalea T, Harrison P, Shackford S, et al. Status of non-operative management of blunt hepatic injuries in 1995: a multicenter experience with 404 patients. J Trauma1996 Jan;40(1):31-38.

6. Croce MA, Fabian TC, Menke PG, Waddle-Smith L, Minard G, Kudsk KA, Patton JH Jr, Schurr MJ, Pritchard FE. Nonoperative management of blunt hepatic trauma is the treatment of choice for haemodynamically stable patients. Ann Surg 1995 Jun;221(6):744-755.

7. Knudson MM, Lim RC Jr, Oakes DD, Jeffery RB Jr. Nonoperative management of blunt liver injuries in adults: the need for continued surveillance. J Trauma 1990 Dec;30(12): 1494-1500.

8. Meredith JW, Young JS, Bowling J, Roboussin D. Non-operative management of blunt hepatic trauma: the exception or the rule? J Trauma 1994 Apr;36(4):529-535.

9. Pachter $\mathrm{H}$, Liang $\mathrm{H}$, Hofstetter $\mathrm{S}$. Liver and biliary tract trauma In: Mattox KL, Feliciano DV, Moore EE, editors. Trauma. 4th ed. New York: McGraw-Hill; 1996. p. 633-680, 681-682.

10. Leppaniemi AK, Mentula PJ, Streng MH, Koivikko MP, Handolin LE. Severe hepatic trauma: non operative management, definitive repair or damage control surgery. World J Surg 2011 Dec;35(12):2643-2649.

11. Helling TS, Ward MR, Balon J. Is the grading of liver injuries a useful clinical tool in the initial management of blunt trauma patient? Eur J Trauma Emerg Surg 2009 Apr;35(2):95-101. 
12. Federico JA, Horner WR, Clark DE, Isler RJ. Blunt hepatic trauma. Nonoperative management in adults. Arch Surg 1990 Jul;125(7):905-909.

13. Yanar H, Ertekin C, Taviloglu K, Kabay B, Bakkaloglu H, Guloglu R. Nonoperative treatment of multipleintra-abdominal solid organ injury after blunt abdominal trauma. J Trauma 2008 Apr;64(4):943-948.

14. Velmahos GC, Toutouzas K, Radin R, Chan L, Rhee P, Tillou A, Demetriades D. High success with nonoperative management of Blunt Hepatic Trauma: the liver is a sturdy organ. Arch Surg 2003 May;138(5):475-481.

15. Gad MA, Saber A, Farrag S, Shams ME, Ellaban GM. Incidence, patterns, and factors predicting mortality of abdominal injuries in trauma patients. N Am J Med Sci 2012 Mar;4(3):129-134.

16. Magray M, Shahdhar M, Wani M, Shafi M, Sheikh J, Wani H. Studying the role of computed tomography in selective management of blunt abdominal trauma patients in a single tertiary care centre In Northern India. Internet J Surg 2013;30(2):1-5.

17. Emery KH, McAneney CM, Racadio JM, Johnson ND, Evora DK, Garcia VF. Absent peritoneal fluid on screening trauma ultrasonography in children: a prospective comparison with computed tomography. J Pediatr Surg 2001 Apr;36(4):565-569.
18. Ekiz F, Yucel T, Emergen I, Gurdal SO, Gonullu D, Yankol Y. The comparison of the results of the conservative treatment between isolated solid organ injuries and those injuries associated with extra-abdominal injuries after blunt abdominal trauma. Ulus Travma Acil Cerrahi Derg 2003 Jan;9(1):23-29.

19. Rutledge R, Hunt JP, Lentz CW, Fakhry SM, Meyer AA, Baker CC, Sheldon GF. A statewide, population based timeseries analysis of the increasing frequency of non-operative management of abdominal solid organ injury. Ann Surg 1995 Sep;222(3):311-326.

20. Sartorelli KH, Frumiento C, Rogers FB, Osler TM. Nonoperative management of hepatic, splenic and renal injures in adults with multiple injuries. J Trauma 2000 Jul;49(1):56-62.

21. Duane TM, Como JJ, Bochicchio GV, Scalea TM. Re-evaluating the management and outcomes of severe blunt liver injury. J Trauma 2004 Sep;57(3):494-500.

22. Fischer RP, Miller-Crotchet P, Reed RL 2nd. The hazards of non-operative management of adults with blunt abdominal injury. J Trauma 1988 Oct;28(10):1445-1449.

23. Kemmeter PR, Hoedema RE, Foote JA, Scholten DJ. Concomitant blunt enteric injuries with injuries of the liver and spleen: a dilemma for trauma surgeons. Am Surg 2001 Mar;67(3):221-226.

24. Sherck JP, Oakes DD. Intestinal injuries missed by computed tomography. J Trauma 1990 Jan;30(1):1-7. 